\title{
Cost of Treatment Demam Berdarah Dengue (DBD) di Rawat Inap Berdasarkan Clinical Pathway di RS X Jakarta
}

\author{
Analysis of Cost of Treatment for Dengue Hemorrhagic Fever Based on Clinical Pathway in RS \\ X Jakarta
}

\author{
Vera Marietha Meinar Rejeki ${ }^{1}$, Atik Nurwahyuni ${ }^{2}$ \\ ${ }^{1}$ Program Studi Kajian Administrasi Rumah Sakit, Fakultas Kesehatan Masyarakat, Universitas Indonesia, Depok, Indonesia \\ ${ }^{2}$ Departemen Administrasi dan Kebijakan Kesehatan, Kesehatan Masyarakat, Universitas Indonesia, Depok, Indonesia
}

Korespondensi: Vera Marietha,

e-mail:veramarietha@gmail.com

\begin{abstract}
Abstrak
Rumah Sakit sebagai pemberi layanan kesehatan saat ini dituntut untuk melakukan kendali mutu dan biaya, namun tetap berkualitas. Clinical pathway yang menjadi dasar pengendalian mutu dan biaya sudah ada tetapi belum diaudit penggunaannya oleh tim rumah sakit. Penelitian ini bertujuan untuk mengetahui unit cost layanan dan cost of treatment DBD di RS X Jakarta. Penelitian kuantitatif melalui pengambilan data cross sectional dengan jumlah sampel penelitian sebanyak 190 pasien DBD. Hasil penelitian didapatkan adanya kesenjangan antara cost of treatment perawatan pasien DBD berdasarkan clinical pathway (Rp. 2.184.588) dan cost of treatment berdasarkan kondisi riil (Rp. 2.382.512) dengan selisih terbesar di rawat inap dan obat-obatan. Cost of treatment tanpa perhitungan gaji dan investasi untuk pasien DBD dapat berkurang menjadi $29 \%$ dari cost of treatment semula. Cost of Treatment tanpa perhitungan gaji maka cost of treatment dapat turun menjadi $42 \%$. Diperlukan sistem pemantauan kepatuhan terhadap clinical pathway, pembentukan tim casemix rumah sakit untuk pemantauan dan evaluasi implementasi JKN di rumah sakit.

Kata Kunci: clinical pathway, cost of treatment, demam berdarah dengue, unit cost
\end{abstract}

\begin{abstract}
Hospitals as health care providers are now required to perform cost and quality control without neglecting the quality of services. Clinical pathways which underlying quality and cost control in the hospital are available but has not been audited. This study aims to determine the unit cost of services in RSX Jakarta, the utilization of hospital services for dengue disease and cost of treatment of DHF in RSX Jakarta. A cross-sectional study was performed in this study. A quantitative approach was done through data collection from hospital information system, medical record and financial data. The result showed that there was a gap between the cost of treatment of DHF patients which based on the clinical pathway (2,184,588 IDR) and the cost of treatment based on the real condition (2,382,512 IDR). The biggest difference between cost of treatment and real cost was in the hospitalization cost and medicine cost. Cost of treatment without salary and investation calculation for DHF patients can be reduced significantly by $29 \%$. Cost of treatment without salary calculation for DHF patients can be reduced significantly by $42 \%$. There is a need for monitoring system and the establishment of hospital case mix team in order to optimize the hospital clinical pathway in the JKN era.

Keyword: clinical pathway, cost of treatment, dengue hemorrhagic fever, unit cost
\end{abstract}

\section{Pendahuluan}

Program Jaminan Kesehatan Nasional (JKN) mengubah pola pembiayaan kesehatan di Indonesia dan mengubah paradigma dalam pelayanan kesehatan. Perubahan paradigma yang terjadi yaitu pola kuratif berubah menjadi preventif, adanya kendali mutu dan kendali biaya serta perubahan jasa medis menjadi remunerasi. Salah satu bagian dari upaya kendali mutu dan kendali biaya adalah dengan mengembangkan dan menerangkan konsep clinical pathway. Clinical pathway adalah salah satu alat manajemen penyakit yang banyak dipakai dan telah berkembang pesat dalam 15 tahun terakhir ini. Terutama sejak banyaknya laporan penelitian yang menunjukan bahwa clinical pathway memiliki potensi dalam mengurangi variasi pelayanan yang tidak perlu sehingga dapat meningkatkan outcome klinik dan juga penghematan pemakaian sumber daya.

Pritts (1999) meneliti bahwa terjadi penurunan biaya dan lama rawat inap pada pasien dengan reseksi usus besar yang menggunakan clinical pathway. Hal yang sama juga disimpulkan pada studi oleh Sylvester AM, George M (2014) bahwa dengan penggunaan clinical pathway dapat menurunkan biaya dan lama hari rawat pada pasien asma. Zhu, Li, Feng, et.al (2014) pun menyatakan dalam studinya bahwa clinical pathway terbukti menjadi pendekatan yang 
efektif dalam menurunkan biaya rumah sakit dan lama hari rawat inap tanpa menurunkan mutu pelayanan pada pasien dengan kanker hepatoselular.

Demam Berdarah Dengue (DBD) merupakan ancaman kesehatan masyarakat yang berkembang di negara-negara tropis dan subtropis di Asia dan Amerika Latin. Indonesia sebagai salah satu negara tropis menjadi negara dengan prevalensi kejadian DBD tertinggi sehingga dengan tingginya angka kejadian DBD, masing-masing fasilitas kesehatan harus memperhitungkan beban biaya akibat penyakit ini. Pada tahun 2016, RS X Jakarta merawat 335 pasien DBD. Rata-rata besar tarif yang dibayar pasien untuk perawatan di RS X Jakarta adalah sebesar Rp. 866.464,-. Sedangkan besar klaim BPJS untuk perawatan DBD tanpa komplikasi adalah sebesar Rp. 1.047.100,. Tarif RSUD terlihat lebih kecil dibandingkan dengan klaim yang dibayarkan BPJS, tetapi belum dapat dilihat perbandingannya dengan unit cost .

Unit cost layanan dan pemanfaatan layanan akan dihitung danselanjutnya akan digunakan untuk menghitung cost of treatment pasien DBD berdasarkan clinical pathway. Besaran cost of treatment akan dibandingkan dengan tarif rumah sakit untuk perawatan DBD dan klaim INA-CBG's. Perhitungan cost of treatment harus dibuat dengan meniadakan biaya gaji dan biaya investasi dengan pertimbangan bahwa RS X Jakarta adalah rumah sakit milik pemerintah, dengan bentuk BLUD (Badan Layanan Umum Daerah) dimana gaji dan sebagian besar investasi masih disubsidi. Masalah pembiayaan akan timbul jika gaji ataupun tunjangan tidak lagi disubsidi oleh pemerintah. Oleh karena itu, penelitian ini memiliki tujuan umum untuk menganalisis cost of treatment rawat inap demam berdarah dengue di rawat inap di RS X Jakarta.

\section{Metode Penelitian}

Penelitian ini merupakan penelitian kuantitatif dengan pendekatancross sectional. Data yang dikumpulkan adalah data sekunder dari Sistem Informasi Manajemen Rumah Sakit (SIM RS), catatan rekam medis pasien, dan laporan keuangan rumah sakit tahun 2016. Waktu penelitian dilakukan pada bulan Mei dan Juni tahun 2017.

Populasi penelitian ini adalah seluruh pasien rawat inap dengan kasus DBD tanpa komplikasi sesuai ICD $X$ di Rumah Sakit. Sampel penelitian adalah pasien rawat inap dengan diagnosa utama DBD tanpa kom- plikasi, yang dirawat di Rumah Sakits elama periode 1 Januari 2016 sampai 31 Desember 2016.

Kriteria Inklusi dalam penelitian ini yaitu (1) Pasien demam berdarah dengue, dalam SIM-RS, yang menjalani rawat inap dengan diagnosa masuk dan keluar yang ditandatangani oleh dokter dalam status sembuh; (2) Status rekam medis pasien lengkap; dan (3) Pasien DBD dengan derajat keparahan level 1, tanpa komplikasi dan tanpa penyakit penyerta. Untuk kriteria eksklusi yaitu pasien meninggal, dirujuk, dan pulang atas keinginan sendiri. Dengan menerapkan kriteria inklusi dan eksklusi maka jumlah sampel untuk penelitian ini adalah sebanyak 190 pasien $(n=190)$.

Pengumpulan dan pengolahan data untuk perhitungan cost of treatment dilakukan dengan cara:

1. Perhitungan unit cost menggunakan metode double distribution.

2. Pada output yang heterogen maka perhitungan dilanjutkan dengan relative value unit (RVU)

3. Unit cost yang didapat kemudian dikalikan dengan volume layanan dan fasilitas perawatan pasien DBD berdasarkan clinical pathway untuk mendapatkan cost of treatment berbasis clinical pathway. Dihitung pula cost of treatment perawatan pasien DBD dengan cara mengalikan unit cost dengan pemanfaatan layanan dan fasilitas perawatan pasien DBD dalam kondisi riil.

4. Cost of treatment dengan meniadakan biaya gaji dan investasi dibuat dengan cara menghitung unit cost dari awal dengan meniadakan biaya gaji atau tunjangan dan biaya investasi.

\section{Hasil Penelitian}

Karakteristik pasien dalam penelitian ini dikelompokkan berdasarkan Length of Stay (LOS), umur, jenis kelamin, cara pembayaran, keadaan pulang dan kelas kamar.

Tabel 1. Karakteristik Pasien berdasar LOS dan Umur

\begin{tabular}{lccc}
\hline & Rata-rata & Min & Max \\
\hline $\begin{array}{c}\text { Lama hari } \\
\text { rawat }\end{array}$ & 4,20 hari & 2,0 hari & 7,0 hari \\
\hline $\begin{array}{c}\text { Umur } \\
\text { Pasien }\end{array}$ & 29,47 tahun & 17,0 tahun & $\begin{array}{c}62,0 \\
\text { tahun }\end{array}$ \\
\hline
\end{tabular}

$\overline{\text { Rata-rata lama hari rawat pasien DBD adalah 4,2 }}$ hari dan rata-rata umur pasien sekitar 29 tahun. Berdasarkan jenis kelamin, jumlah antara laki-laki 
(52,11\%) dan perempuan (47,89\%) cenderung sama. Berdasarkan cara pembayaran yaitu sebanyak $52,11 \%$ adalah peserta JKN dan 47,89\% adalah pasien umum (Gambar1).
Di unit IGD pasien DBD menerima layanan yang sama dengan clinical pathway yaitu adanya pemeriksaan oleh dokter IGD dan adanya pemeriksaan penunjang. Pasien kemudian masuk ke unit rawat

Gambar 1. Karakteristik Pasien

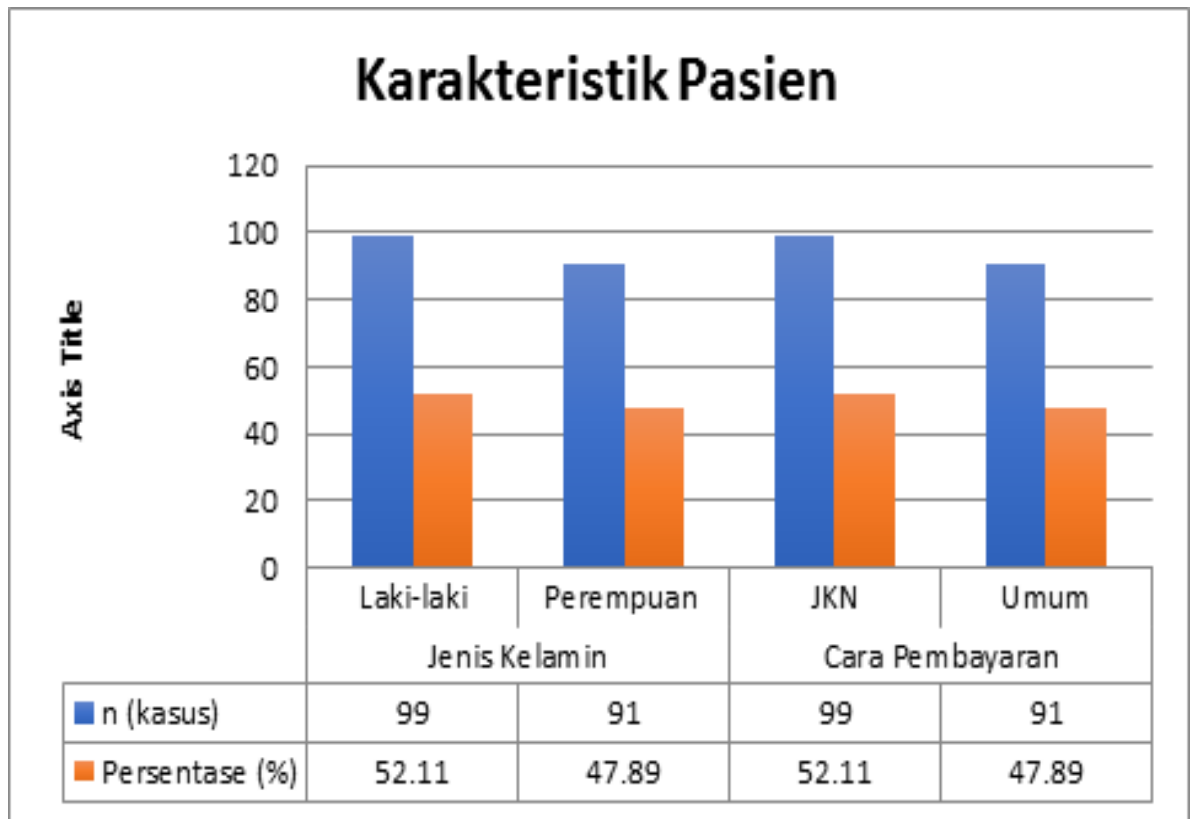

Tabel 2 Pemanfaatan layanan berdasarkan clinical

\begin{tabular}{ccc}
\hline \multicolumn{3}{c}{ pathway } \\
& $\begin{array}{c}\text { Pemanfaatan / } \\
\text { Dosis }\end{array}$ & Jumlah \\
\hline Layanan & 1 kali & 1 kali \\
\hline Rawat Inap & 3 hari & 3 hari \\
\hline visit dokter spesialis & 1 kali / hari & 3 kali \\
\hline Laboratorium & \\
\hline Hematologi rutin & 2 kali / hari & 6 kali \\
\hline Farmasi & \\
\hline Ringer Laktat $500 \mathrm{ml}$ & 4 kali / hari & 12 kali \\
\hline Parasetamol $500 \mathrm{mg}$ & 3 kali / hari & 10 kali \\
\hline Ranitidin injeksi $150 \mathrm{mg}$ & 2 kali / hari & 6 kali
\end{tabular}

inap. Perbandingan dibuat berdasar pemanfaatan layanan yang patuh berdasarkan clinical pathway dan pemanfaatan layanan yang diterima oleh pasien (Tabel 2). Dokter spesialis melakukan visit di rawat inap sebanyak 3 kali, yaitu setiap hari selama perawatan. Sedangkan dari data didapatkan utilisasi dokter spesialis sebanyak 3,36 kali yang berarti dokter visit lebih dari 3 kali selama masa perawatan. Hasil penelitian juga menunjukkan hanya pemeriksaan hematologi rutin yang harus dilakukan dalam pemeriksaan laboratorium (Tabel 3).
Tabel 3 Perbandingkan Visit Dokter dan Pemeriksaan Laboratorium pada pada clinical pathway dan riil

\begin{tabular}{lcc}
\hline & $\begin{array}{c}\text { Clinical } \\
\text { pathway (kali) }\end{array}$ & $\begin{array}{c}\text { Riil } \\
(\mathbf{k a l i})\end{array}$ \\
\hline Visit Dokter & & \\
\hline visit Dokter Spesialis & 3 & 3,36 \\
\hline Pemeriksaan Laboratorium & & \\
\hline Hematologi rutin & 6 & 4,52 \\
Hematologi lengkap & - & 0,92 \\
Widal & - & 0,05 \\
Feses lengkap & - & 0,02 \\
SGOT/SGPT & - & 0,02 \\
Elektrolit & - & 0,01 \\
LED & - & 0,01 \\
Ureum/Kreatinin & - & 0,01 \\
Urin Lengkap & - & 0,01 \\
\hline
\end{tabular}

\section{Alat Kesehan Habis Pakai}

\begin{tabular}{lll}
\hline Spuit $3 \mathrm{cc}$ & 6 & 7,71 \\
Infus set & 1 & 1,01 \\
IV catheter no. 20 & 1 & 0,96 \\
Spuit $10 \mathrm{cc}$ & - & 0,42 \\
Spuit $5 \mathrm{cc}$ & - & 0,42 \\
Spuit $1 \mathrm{cc}$ & - & 0,07 \\
IV catheter no. 22 & - & 0,05 \\
\end{tabular}


Tabel 4. Perbandingan Pemanfaatan layanan farmasi obat-obatan berdasarkan clinical pathway dan riil

\begin{tabular}{|c|c|c|}
\hline Obat-obatan & $\begin{array}{l}\text { Clinical path- } \\
\text { way (kali ) }\end{array}$ & $\begin{array}{c}\text { Riil } \\
\text { (kali) }\end{array}$ \\
\hline \multicolumn{3}{|l|}{ Cairan kristaloid } \\
\hline Ringer Laktat Infus & 12 & 10,95 \\
\hline Asering infus & - & 0,13 \\
\hline \multicolumn{3}{|l|}{ Antipiretik/analgetik } \\
\hline Parasetamol tablet $500 \mathrm{mg}$ & 10 & 8,05 \\
\hline $\begin{array}{l}\text { Asam mefenamat tablet } 500 \\
\mathrm{mg}\end{array}$ & - & 0,02 \\
\hline Tramadol injeksi $50 \mathrm{mg}$ & - & 0,02 \\
\hline Parasetamol drip 1 gram & - & 0,01 \\
\hline \multicolumn{3}{|l|}{ Penurun asam lambung } \\
\hline Ranitidin injeksi $50 \mathrm{mg}$ & 6 & 4,69 \\
\hline Ondansentron injeksi $4 \mathrm{mg}$ & 0 & 2,94 \\
\hline Domperidone tablet $10 \mathrm{mg}$ & 0 & 1,05 \\
\hline Ranitidin tablet $150 \mathrm{mg}$ & 0 & 0,63 \\
\hline Omeprazole injeksi $40 \mathrm{mg}$ & 0 & 0,13 \\
\hline Antasid tablet & 0 & 0,11 \\
\hline Omeprazole kapsul $40 \mathrm{mg}$ & 0 & 0,08 \\
\hline Ondansentron tablet $4 \mathrm{mg}$ & 0 & 0,08 \\
\hline Lansoprazole kapsul & 0 & 0,05 \\
\hline Antasid sirup & 0 & 0,04 \\
\hline Prosogan injeksi & 0 & 0,04 \\
\hline Sukralfat sirup & 0 & 0,02 \\
\hline Lansoprazol injeksi & 0 & 0,01 \\
\hline Pantoprazol injeksi & 0 & 0,01 \\
\hline \multicolumn{3}{|l|}{ Lain-lain } \\
\hline Dexametasone injeksi & 0 & 1,26 \\
\hline Water for injection & 0 & 0,38 \\
\hline $\begin{array}{l}\text { Metil prednisolone tablet } 4 \\
\text { mg }\end{array}$ & 0 & 0,02 \\
\hline Neurobion injeksi & 0 & 0,01 \\
\hline
\end{tabular}

Dalam clinical pathway alkes yang digunakan adalah sesuai obat dan infus yang digunakan yaitu spuit 3 cc sebanyak 6 kali, infus set sebanyak 1 kali dan intravena catheter nomor 20 sebanyak 1 kali. Dalam kondisi riil terlihat penggunaan spuit $3 \mathrm{cc}$ dan infus set melebihi clinical pathway (Tabel 3). Pemanfaatan untuk obat-obatan dikelompokkan menjadi tiga kelompok obat yaitu cairan kristaloid, antipiretik analgetik, dan penurun asam lambung (Tabel 4).

Perhitungan unit cost atau biaya satuan dalam penelitian ini menggunakan metode double distribution.
Tabel 5. Total Cost dan Unit cost Homogen

\begin{tabular}{|c|c|c|c|}
\hline Nama Unit & Total Cost & $\begin{array}{l}\text { Util- } \\
\text { isasi }\end{array}$ & Unit cost \\
\hline IGD & $3,628,783,437$ & 15030 & 241,436 \\
\hline $\begin{array}{l}\text { Poli Obstetri dan } \\
\text { Ginekologi }\end{array}$ & $1,732,248,627$ & 5678 & 305,081 \\
\hline Poli Bedah & $253,296,643$ & 154 & $1,644,783$ \\
\hline $\begin{array}{l}\text { Poli Tumbuh } \\
\text { Kembang }\end{array}$ & $609,148,932$ & 561 & $1,085,827$ \\
\hline Poli Anak & $1,013,634,894$ & 5683 & 178,363 \\
\hline $\begin{array}{l}\text { Poli Penyakit } \\
\text { Dalam }\end{array}$ & $1,197,909,783$ & 6120 & 195,737 \\
\hline Poli Gizi & $780,790,059$ & 121 & $6,452,810$ \\
\hline Poli Syaraf & $678,199,443$ & 1616 & 419,678 \\
\hline Poli Gigi & $2,392,763,063$ & 3494 & 684,821 \\
\hline Poli THT & $592,309,451$ & 705 & 840,155 \\
\hline Farmasi & $2,585,110,549$ & 42698 & 60,544 \\
\hline Laboratorium & $3,266,191,202$ & 20073 & 162,716 \\
\hline Radiologi & $1,468,830,594$ & 2548 & 576,464 \\
\hline Fisioterapi & $427,655,099$ & 1113 & 384,236 \\
\hline $\mathrm{MCU}$ & $860,395,081$ & 5522 & 155,812 \\
\hline Ambulans & $825,149,463$ & 879 & 938,737 \\
\hline $\begin{array}{l}\text { Rawat Inap De- } \\
\text { wasa }\end{array}$ & $1,921,341,040$ & 3979 & 482,870 \\
\hline Rawat Inap Anak & $1,419,733,216$ & 1410 & $1,006,903$ \\
\hline $\begin{array}{l}\text { Rawat Inap Ke- } \\
\text { bidanan }\end{array}$ & $2,531,379,204$ & 631 & $4,011,694$ \\
\hline $\begin{array}{l}\text { High Care Unit } \\
(\mathrm{HCU})\end{array}$ & $568,134,688$ & 36 & $15,781,519$ \\
\hline $\begin{array}{l}\text { Kamar Operasi } \\
(\mathrm{OK})\end{array}$ & $1,897,820,166$ & 14 & $135,558,583$ \\
\hline $\begin{array}{l}\text { Ruang Bersalin } \\
\text { (VK) }\end{array}$ & $2,299,619,340$ & 439 & $5,238,313$ \\
\hline Kamar Jenazah & $186,053,868$ & 44 & $4,228,497$ \\
\hline
\end{tabular}

Terlebih dahulu dilakukan identifikasi unit produksi dan penunjang, identifikasi biaya langsung dan biaya tidak langsung. Dalam alokasi tahap I, pengalokasian dilakukan dari unit penunjang ke unit penunjang lainnya dan unit produksi, dan pada alokasi tahap II, semua biaya yang masih tersisa pada unit penunjang didistribusikan habis ke unit produksi. Setelah distribusi biaya habis ke unit produksi, maka akan didapat total biaya pada unit-unit produksi. Kemudian total biaya tersebut dibagi dengan jumlah hari perawatan atau jumlah kunjungan untuk mendapatkan unit cost (Tabel 5).

Biaya satuan di IGD dan Laboratorium dilakukan perhitungan RVU. Perhitungan RVU dilakukan pada unit dengan tindakan heterogen. Setelah mendapat 
unit cost dari masing-masing unit produksi maka dilakukan perhitungan cost of treatment pasien. Cost of treatment didapatkan dari hasil perkalian unit cost dengan utilisasi. Untuk data harga obat dan alkes yang dimasukkan dalam perhitungan cost of treatment diambil dari harga pembelian. Perbandingan cost of treatment perawatan pasien berdasarkan clinical pathway dapat dilihat pada tabel 6 .

Perhitungan cost of treatment pada tabel 6 dilakukan juga pada 189 pasien lainnya sesuai dengan riil pemanfataan layanan tiap pasien. Cost of treatment untuk 190 pasien tersebut dihitung dan kemudian dihtiung rata-rata sehingga dihasilkan rata-rata cost of treatment perawatan DBD pada kondisi real adalah Rp. 2.382.513. Tabel 7 memperlihatkan perbandingan cost of treatment perawatan pasien berdasarkan clinical pathway dan cost of treatment pada kondisi riil, sehingga dapat dilihat layanan yang memberikan kontribusi biaya terbesar.

Tabel 6. Cost of treatment perawatan pasien berdasarkan clinical pathway dan rill untuk satu pasien

\begin{tabular}{|c|c|c|c|c|c|}
\hline \multirow{2}{*}{ Jenis Pelayanan } & \multicolumn{2}{|c|}{ Pemanfaatan layanan } & \multirow{2}{*}{ Unit cost } & \multicolumn{2}{|c|}{ Cost of treatment } \\
\hline & cp & riil (satu pasien) & & $\mathbf{c p}$ & riil (satu pasien) \\
\hline \multicolumn{6}{|l|}{ IGD } \\
\hline Konsultasi & 1 & 1 & 92,259 & 92,259 & 92,259 \\
\hline Pemasangan infus & 1 & 1 & 79,250 & 79,250 & 79,250 \\
\hline Injeksi & 1 & 1 & 29,142 & 29,142 & 29,142 \\
\hline \multicolumn{6}{|l|}{ Rawat Inap } \\
\hline $\begin{array}{l}\text { Perawatan di rawat inap } \\
\text { (LOS) }\end{array}$ & 3 & 4 & 482,870 & $1,448,611$ & $1,931,481$ \\
\hline \multicolumn{6}{|l|}{ Pemeriksaan Penunjang } \\
\hline Hematologi rutin & 6 & 4 & 66,214 & 397,282 & 264,854 \\
\hline Hematologi Lengkap & - & 1 & 68,331 & - & 68,331 \\
\hline Widal & - & 1 & 75,538 & - & 75,538 \\
\hline \multicolumn{6}{|l|}{ Farmasi } \\
\hline RL & 12 & 14 & 7,150 & 85,800 & 100,100 \\
\hline Parasetamol & 10 & 12 & 87 & 870 & 1,044 \\
\hline Ranitidin inj & 6 & 7 & 3,020 & 18,120 & 840 \\
\hline Ondansetron inj & - & 12 & 1,650 & - & 19,800 \\
\hline Abbocath no. 20 & 1 & 1 & 12,284 & 12,284 & 12,284 \\
\hline Infus Set Makro & 1 & 1 & 16,063 & 16,063 & 16,063 \\
\hline \multirow[t]{2}{*}{ Spuit $3 \mathrm{cc}$} & 6 & 12 & 818 & 4,908 & 9,816 \\
\hline & To & & & $2,184,588$ & $2,715,877$ \\
\hline
\end{tabular}

Tabel 7. Perbandingan Cost of treatment berdasar Clinical pathway dan Kondisi Riil

\begin{tabular}{ccc}
\hline & \multicolumn{2}{c}{ Cost of treatment } \\
\cline { 2 - 3 } Pemanfaatan Layanan & Clinical pathway & Kondisi Riil \\
\hline IGD & 200,651 & 205,931 \\
\hline Rawat Inap & $1,448,611$ & $1,637,721$ \\
\hline Pemeriksaan Penunjang & 397,282 & 375,646 \\
\hline Farmasi & 138,045 & 159,559 \\
\hline Total Cost of treatment & $\mathbf{2 , 1 8 4 , 5 8 8}$ & $\mathbf{2 , 3 8 2 , 5 1 3}$ \\
\hline
\end{tabular}


Tabel 8. Perbandingan Cost of treatment dengan Perhitungan Total Cost, Perhitungan Tanpa Gaji dan Perhitungan Tanpa Gaji dan Investasi

\begin{tabular}{lccc}
\hline \multirow{2}{*}{ Perawatan Pasien DBD } & Full Cost & Tanpa Gaji & $\begin{array}{c}\text { Tanpa Gaji dan } \\
\text { Investasi }\end{array}$ \\
\cline { 2 - 4 } & & & \\
\hline Berdasar Clinical pathway & 200,651 & 53,132 & 24,243 \\
\hline GGD & $1,448,611$ & 519,761 & 344,383 \\
\hline Rawat Inap & 397,282 & 209,776 & 129,126 \\
\hline Laboratorium & 138,045 & 138,045 & 138,045 \\
\hline Farmasi & $\mathbf{2 , 1 8 4 , 5 8 8}$ & $\mathbf{9 2 0 , 7 1 5}$ & $\mathbf{6 3 5 , 7 9 7}$ \\
\hline Cost of treatment berdasar & & & \\
Clinical Pathway & & 54,530 & 24,881 \\
\hline Kondisi Riil & 205,931 & 389,432 \\
\hline IGD & $1,637,721$ & 587,791 & 122,093 \\
\hline Rawat Inap & 375,646 & 198,351 & 159,559 \\
\hline Laboratorium & 159,559 & 159,559 & $\mathbf{6 9 9 , 6 2 2}$ \\
\hline Farmasi & $\mathbf{2 , 3 8 2 , 5 1 3}$ & $\mathbf{1 , 0 0 3 , 8 8 8}$ \\
\hline Cost of treatment kondisi riil & &
\end{tabular}

Gambar 2. Perbandingan Cost of treatment, Klaim BPJS dan Rata-rata Besar Tarif yang dibayar Pasien

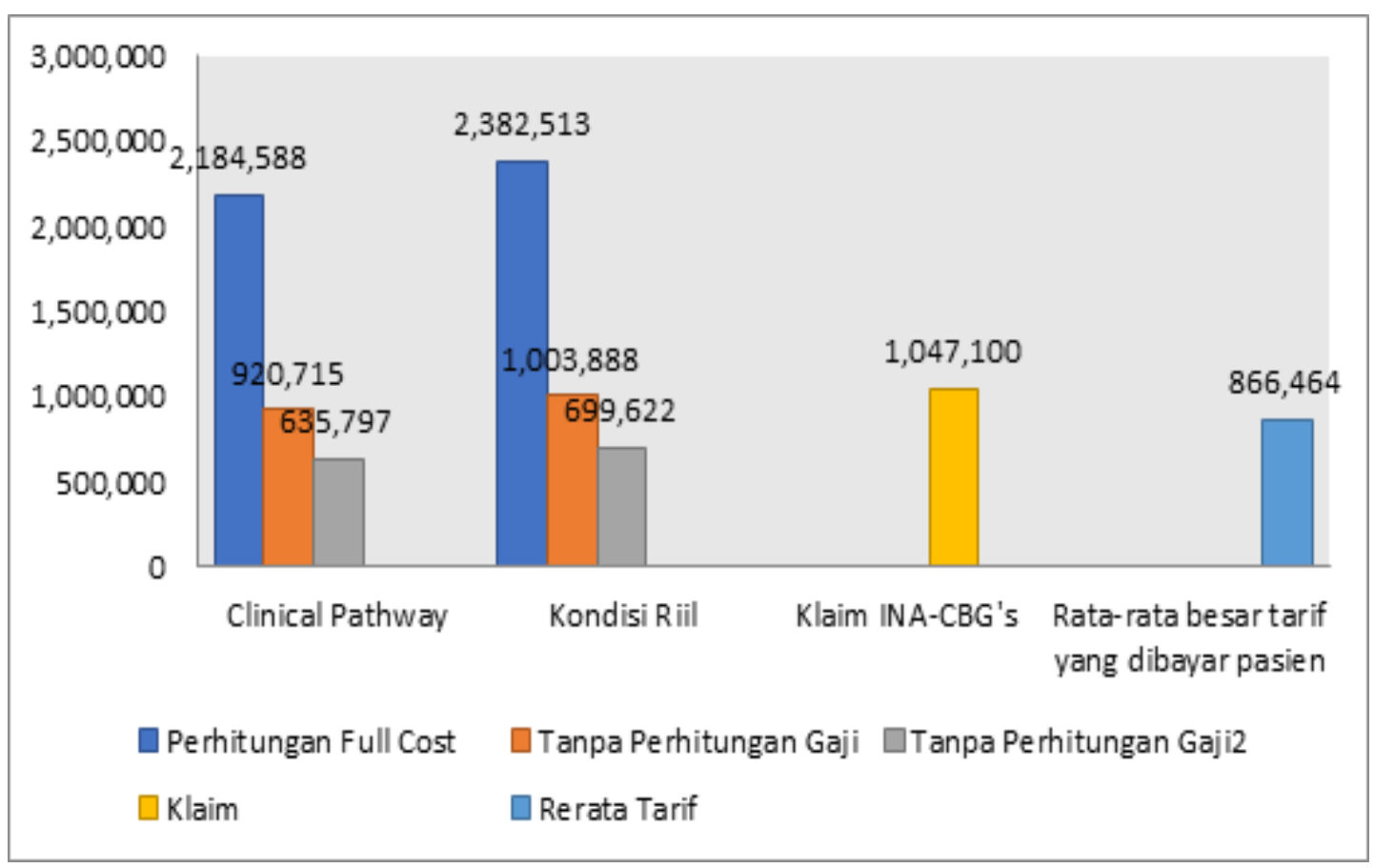

Perhitungan cost of treatment juga dibuat dengan meniadakan biaya gaji daninvestasi. Hal ini dilakukan untuk melihat biaya yang harus dikeluarkan rumah sakti dengan lebih jelas. Dikarenakan selama ini gaji dan sebagin besar investasi masih disubsidi oleh pe- merintah. Nantinya dengan perhitungan cost of treatment yang tepat dengan memperhitungkan subsidi dari pemerintah maka dapat pula dibandingkan dengan tarif yang ada saat ini dan besaran klaim INACBG's untuk rumah sakit tipe D milik pemerintah 
Tari tabel 8 dapat dilihat bahwa tanpa perhitungan gaji dan investasi maka cost turun menjadi sebesar 29\% dari biaya semula. Apabila dihitung tanpa perhitungan gaji maka cost of treatment dapat turun menjadi $42 \%$ dari biaya semula.

Dari gambar 2 dapat dilihat bahwa klaim INACBG's (Rp. 1.047.000) masih lebih besar dari perhitungan cost of treatment tanpa perhitungan gaji dan investasi (Rp. 699.622) dan cost of treatment tanpa gaji saja (Rp. 1.003.888). Sedangkan besar tarif yang harus dibayar pasien lebih besar dari perhitungan cost of treatment tanpa gaji dan investasi.

\section{Pembahasan}

\section{Karakteristik Pasien}

Karakteristik pasien dalam penelitian ini dilihat dari karakteristik umur dan jenis kelamin. Data dari Infodatin (Kemenkes, 2016) menunjukkan kejadian DBD sebagian besar terjadi pada usia dewasa, walaupun kejadian DBD tidak tergantung dari umur. Jumlah laki-laki dan perempuan dalam penelitian ini tidak terlalu berbeda. Hasil sesuai dengan data distribusi kasus DBD di Indonesia pada tahun 2012 2015 berdasarkan jenis kelamin cenderung sama.

Penelitian Perwira, Ita (2011) menyatakan bahwa proporsi jumlah laki-laki dan perempuan yang dirawat inap karena infeksi virus Dengue tidak jauh berbeda, yaitu laki-laki 51,8\% dan perempuan 48,2\%. Rumah sakit merupakan RS tipe D yang hanya merawat pasien dengan severity level 1 dan level 2 awal.

Lama hari rawat sesuai clinical pathway RS X Jakarta adalah 3 hari. Hal ini disebabkan melihat derajat keparahan penyakit, yaitu DBD dengan keparahan level 1 dan juga melihat contoh dari rumah sakit lainnya di Jakarta yang sudah menerapkan kendali mutu dan kendali biaya. Dalam penelitian didapatkan rata-rata lama hari rawat adalah selama 4,20 hari, lebih tinggi daripada clinical pathway. Sulastomo (1997) menyatakan rata-rata lama hari rawat berkaitan dengan adanya tindakan operasi, penyakit pemberat dan penyakit penyerta yang dialami pasien serta sistem pembayaran.

Tobing (2011) menyatakan bahwa rata-rata lama hari rawat pada diagnosis DBD tanpa penyulit di RSUD di Jakarta adalah 4,7 hari. Widjaja (2009) dalam penelitiannya menyatakan bahwa LOS di RSUD Cengkareng, RSUD Pasar Rebo, RSUD Budi Asih dan RSUD Koja secara berturut-turut adalah: 4,8 hari, 6,5 hari, 5,5 hari dan 5 hari. Primasari
(2015) dalam penelitiannya di Instalasi Rawat Inap RS Fatmawati periode Januari-Juni 2015 mendapatkan data rata-rata lama rawat pasien DBD adalah 5,32 hari. Lama hari rawat yang sesuai dengan formulir clinical pathway sebesar 63,6\%. Dalam waktu satu tahun setelah penggunaan clinical pathway terdapat pengurangan LOS pasien DBD anak dari 5,32 hari menjadi 3,95 hari. Terjadi variasi pada lama hari rawat karena kondisi perjalanan penyakit, penyakit penyerta, atau komplikasi maupun kesalahan medis.

Kementrian Kesehatan (2014) menyatakan adanya variasi pada implementasi clinical pathway dapat disebabkan oleh beberapa faktor, yaitu: sifat penyakit pada individu tertentu, terapi tidak diberikan sesuai dengan ketentuan, pasien tidak mentoleransi obat, dan terdapat komorbiditas yaitu penyakit lain selain penyakit utama. Hal yang perlu ditekankan adalah penerapan clinical pathway dapat mengurangi lama hari rawat sehingga dapat meminimalisir sumber daya dan biaya yang dikeluarkan rumah sakit. Hari rawat yang semakin bertambah akan menyebabkan bertambahnya biaya baik biaya obat, alkes, kamar, yang berhubungan dengan rawat inap.

\section{Pemanfaatan Layanan Pasien DBD}

Jumlah visit dokter spesialis berdasarkan clinical pathway lebih kecil dari kondisi riil. Hal ini dikarenakan jumlah hari rawat pada kondisi riil lebih banyak (rata-rata 4,2 hari) sehingga visit pun semakin banyak. Pemeriksaan penunjang yang dilakukan sesuai clinical pathway adalah pemeriksaan hematologi rutin sebanyak 6 kali. Sedangkan dalam penelitian didapatkan rata-rata utilisasi hematologi rutin sebanyak 4,52 kali selama perawatan, tetapi didapatkan tambahan pemeriksaan lain seperti: hematologi lengkap, tes Widal, feses lengkap, SGOT/SGPT, elektrolit, feses rutin, LED, ureum kreatinin, dan urin lengkap. Menurut Schultz, R (1990) seperti dikutip Zailani, mengatakan hampir $80 \%$ dari pemeriksaan dan pemeliharaan kesehatan dipengaruhi oleh dokter, karena seluruh pelayanan dilakukan berdasarkan instruksi dokter. Penggunaan clinical pathway dapat meningkatkan efisiensi pemeriksaan penunjang.

Penggunaan obat-obatan sesuai clinical pathway adalah terapi simptomatik yaitu berupa terapi cairan yaitu infus Ringer Laktat, antipiretik dan penurun asam lambung. Penggunaan obatnya pun sesuai lama rawat. Dalam penelitian memang didapatkan penggunaan jumlah obat utama seperti cairan ringer laktat, parasetamol dan ranitidine masih lebih kecil 
dari penggunaan di rumah sakit. Tetapi jenis obat yang digunakan bertambah banyak, Widjaja (2009) dalam penelitiannya di RSUD Cengkareng meneliti bahwa obat-obatan inti yang dipakai selama masa perawatan DBD adalah: Parasetamol, Ranitidin tablet, Ranitidin injeksi, dan infus Ringer Laktat. Terdapat juga obat-obat tambahan seperti Lesicol tablet, Oralit, Antasida sirup, Ondansentron, dan Vitamin B Kompleks.

Salah satu obat yang digunakan di RS X Jakarta adalah obat golongan kortikosteroid. Zhang dan Kramer (2014) dalam penelitiannya menyatakan bahwa penggunaan kortikosteroid dalam terapi DBD untuk mencegah syok belum dapat dibuktikan, tetapi kenyataanya obat tersebut masih digunakan di rumah sakit.Utilisasi alkes pada mengikuti obatobatan yang digunakan. Sehingga jika macam obat yang digunakan semakin banyak maka utilisasi alkes pun akan makin beragam.

\section{Cost of Treatment perawatan pasien DBD}

Berdasarkan hasil penelitian dapat dilihat bahwa komponen terbesar dari cost of treatment adalah rawat inap. Komponen biaya disini termasuk akomodasi rawat inap dan visit dokter spesialis. Penelitian menunjukkan bahwa besaran biaya yang dibutuhkan selama pasien dirawat dari mulai pendaftaran sampai pulang sangat dipengaruhi lama hari rawat. Komponen biaya yang terbesar selanjutnya adalah biaya farmasi. Makin lama pasien dirawat maka obat-obatan dan alkes yang diterima akan semakin besar biayanya.

Dari hasil penelitian Tobing (2011) didapatkan komposisi biaya rawat inap kasus DBD di lima rumah sakit, dimana komponen tertinggi di urutan pertama dan kedua adalah obat, pemeriksaan penunjang baru diikuti oleh komponen lainnya secara bervariasi. Hal ini sesuai dengan penatalaksanaan pengobatan DBD yang bersifat suportif dengan pemberian cairan infus, dan obat-obatan simptomatik untuk mengatasi gejala yang timbul apabila diperlukan, misalnya antipiretik atau penurun demam. Kisaran rerata biaya yang cukup lebar dari tiap pasien disebabkan karena tidak konsistennya petugas kesehatan dalam melaksanakan standar pedoman pengobatan kasus DBD yang sudah ada.

Ada atau tidaknya clinical pathway sangat berpengaruh terhadap besaran biaya. Bila suatu Rumah Sakit belum memiliki clinical pathway untuk suatu kasus penyakit, akan sulit diprediksikan besaran bi- aya pelayanan kesehatan. Hal ini dapat terlihat dalam penelitian bahwa cost of treatment existing di RS X Jakarta lebih besar daripada cost of treatment clinical pathway yang ada. Dalam hal ini, clinical pathway sudah dimiliki oleh rumah sakit tetapi ternyata tidak digunakan. Dapat dilihat dari selisih cost of treatment antara keduanya yaitu sebesar Rp. 197.925,-. Jika biaya ini dikalikan dengan jumlah pasien (190 orang), maka efisiensi yang dapat terjadi selama 1 tahun dengan penggunaan clinical pathway adalah sebesar Rp. 37.605.750,--

Hasil penelitian menunjukkan bahwa cost of treatment tanpa perhitungan gaji untuk pasien DBD berkurang signifikan sehingga besarannya menjadi 42\% dari cost of treatment existing, dan cost of treatment tanpa perhitungan gaji dan investasi besarannya menjadi $29 \%$ dari cost of treatment existing. Hal ini senada dengan penelitian Rinawati (2016) yang menyatakan bahwa RS milik pemerintah sebaiknya membuat simulasi perhitungan cost dengan perbandingan di atas. Hal ini perlu dilakukan untuk menghindari biaya berulang maka biaya perawatan DBD yang dapat diajukan RS X Jakarta adalah biaya perawatan yang tidak mengikutsertakan gaji dan investasi..

Cost of treatment ini dapat menjadi acuan jika dibandingkan dengan klaim BPJS untuk pasien DBD, sebesar Rp. 1.047.100,-. Besaran klaim masih lebih besar daripada perhitungan cost of treatment tanpa gaji. Hal ini seharusnya menjadi suatu kewajaran di RS X Jakarta bila rumah sakit masih mendapatkan subsidi untuk take home pay pegawai dan investasi. Tetapi bila nantinya RS X Jakarta menjadi BLUD penuh dimana untuk gaji ataupun tunjangan pegawai sudah tidak diberikan subsidi, maka rumah sakit sudah harus memikirkan efisiensi.

Tarif yang ada pun dapat dibandingkan dengan cost of treatment yang ada. Rata-rata tarif yang harus dibayar memang masih lebih besar dari perhitungan cost of treatment tanpa gaji dan investasi. Hal ini dapat menjadi dasar pertimbangan dalam menyusun tarif rumah sakit nantinya. Tarif yang ada belum disusun berdasar unit cost, sehingga harus diperbaharui, selain dengan unit cost dibutuhkan juga pertimbangan tarif rumah sakit lain, aturan dinas kesehatan dan branding. Tarif yang dibuat pun harus didasarkan pada perhitungan sesuai dengan keadaan yang ada jika nantinya rumah sakit tidak lagi disubsidi atau jika subsidinya berkurang. 
Efisiensi ataupun kendali biaya dapat dibuat dari berjalannya clinical pathway untuk perawatan penyakit di rawat inap. Clinical pathway harus dipatuhi oleh setiap pegawai rumah sakit dan manajemen juga membuat sistem agar pegawai dapat mematuhinya. Dengan penggunaan clinical pathway oleh petugas rumah sakit, diharapkan kendali mutu dan kendali biaya di rumah sakit dapat tercapai.

\section{Kesimpulan dan Saran \\ Kesimpulan}

Terdapat perbedaan antara cost of treatment perawatan pasien DBD berdasarkan clinical pathway (Rp. 2.184.588) dan cost of treatment berdasarkan kondisi riil (Rp. 2.382.512), dengan perbedaan terbesar di rawat inap dan obat-obatan. Selisih cost of treatment antara kedua kondisi tersebut yaitu sebesar Rp. 197.925,-. Jika biaya ini dikalikan dengan jumlah pasien (190 orang), maka efisiensi yang dapat terjadi selama 1 tahun dengan penggunaan clinical pathway adalah sebesar Rp. 37.605.750. Hasil penelitian menunjukkan bahwa cost of treatment tanpa perhitungan gaji untuk pasien DBD berkurang secara signifikan sebesar 42\% dari cost of treatment existing, dan cost of treatment tanpa perhitungan gaji dan investasi besarannya menjadi 29\% dari cost of treatment existing.

\section{Saran}

Diperlukannya sistem pemantauan kepatuhan terhadap clinical pathway. Pembentukan tim casemix rumah sakit untuk pemantauan dan evaluasi implementasi JKN di rumah sakit.

\section{Daftar Pustaka}

Kementerian Kesehatan RI. 2016. Infodatin Situasi DBD. Jakarta: Pusat data dan informasi Kemenkes RI.

Kementerian Kesehatan Republik Indonesia. 2013. Pedoman Pengendalian Demam Berdarah Dengue di Indonesia. Direktorat Jenderal Pengendalian Penyakit dan Penyehatan Lingkungan.

Kementerian Kesehatan Republik Indonesia. 2014. Pedoman Penyusunan Standar Pelayanan Kedokteran. Konsorsium Upaya Kesehatan Direktorat Jendral Bina Upaya Kesehatan.

Laporan Tahunan RS X Jakarta tahun 2016

Perwira, Ita, 2011. Faktor - Faktor Yang Mempengaruhi Lama RI Pada Pasien Yang Terinfeksi Vi- rus Dengue Di RSUP Persahabatan Jakarta Timur. Depok. Universitas Indonesia

Primasari, R. 2015. Analisis Lama Hari Rawat pada Pasien BPJS dengan Kasus Demam Berdarah Dengue di Instalasi Rawat Inap RSUP Fatmawati periode Januari-Agustus tahun 2015. Depok. Universitas Indonesia

Pritts T, Nussbaum M, Flesch L, et.al. 1999. Implementation of a Clinical Pathway Decreases Length of Stay and Cost for Bowel Resection. Annals of Surgery. Nov; 230(5): 728. Diakses dari https://www. ncbi.nlm.nih.gov/pmc/articles/PMC $1420929 /$ tanggal 10 April 2018.

Sulastomo. 1997. Asuransi Kesehatan dan Managed Care, PT. Asuransi Kesehatan Indonesia. Jakarta

Sunarto E, Dewi A. 2016. Membangun Tata Kelola Klinis Melalui Clinical Pathway Demam Berdarah Dengue RSU Rizki Amalia Medika. Jurnal Medicoeticoilegal dan Manajemen Rumah Sakit, Vol. 5 No. 2 Juli 2016.

Sylvester AM, George M. 2014. Effect of a clinical pathway on length of stay and cost of pediatric inpatient asthma admissions: an integrative review. Clin Nurs Res 2014 Aug;23(4):384-401. Diakses dari https://www.ncbi.nlm.nih.gov/pubmed/23676186 tanggal 10 April 2018.

Tobing, R. 2013. Analisis Klaim Biaya Rawat Inap Kasus DBD Pasien JPK Gakin dan SKTM di Lima RSUD Provinsi DKI Jakarta Tahun 2011.

Widjaja, B. 2009. Analisa Implementasi Integrated Care Pathway Kasus DBD di Ruangan Rawat Inap Kelas III RSUD Cengkareng tahun 2009. Depok, Universitas Indonesia

Zailani, M. 2003. Jasa Medis di Rumah Sakit, Hopital Management Refresing Course and Exibition, Permapkin, Jakarta.

Zhang F, Kramer CV. 2014. Corticosteroid for treating dengue infection in children and adults. Diakses dari www.cochrane.org/CD003488/INFECTN_ corticosteroids-treating-dengue- infection-children-and-adults tanggal 28 Mei 2017.

Zhu L, Li J, Li XK, et.al. 2014. Impact of a Clinical Pathway on Hospital Costs, Length of Stay and Early Outcomes after Hepatectomy for Hepatocellular Carcinoma. Asian Pacific Journal of Cancer Prevention, Vol 15. Diakses dari https://pdfs.semanticscholar.org/46d1/9451da7ccbf65a09a2c4b13c71f57008507e.pdf tanggal 10 April 2018. 